\title{
Thrown into Limekilns : The Reuse of Statuary and Architecture in Galilee from Late Antiquity onwards
}

\section{Bonnie, Rick}

Routledge - Taylor \& Francis Group

2016-06

Bonnie , R 2016 , Thrown into Limekilns: The Reuse of Statuary and Architecture in Galilee from Late Antiquity onwards . in J Day , R Hakola, M Kahlos \& U Tervahauta (eds), Spaces in Late Antiquity : Cultural, Theological and Archaeological Perspectives . Routledge - Taylor \& Francis Group , Abingdon , pp. 190-211 . https://doi.org/10.5281/zenodo.495881

http://hdl.handle.net/10138/232727

https://doi.org/10.5281/zenodo.495881

unspecified

publishedVersion

Downloaded from Helda, University of Helsinki institutional repository.

This is an electronic reprint of the original article.

This reprint may differ from the original in pagination and typographic detail.

Please cite the original version. 


\title{
10 Thrown into Limekilns
}

\section{The Reuse of Statuary and Architecture in Galilee from Late Antiquity onwards}

\author{
Rick Bonnie
}

\section{Introduction ${ }^{1}$}

In any city of the Roman Empire, inhabitants were surrounded by statuary as they visited theatres, baths, fountains, sanctuaries, and other public spaces. [It] was part of the expected armature of the Roman city, and comprised portraits of emperors and local notables, as well as ... statues of divinities and mythological figures. ${ }^{2}$

The pervasiveness of statuary in Roman cities, as described here by Lea Stirling, is an often-used opening when discussing the social role and meaning of sculpture in the Roman Empire. ${ }^{3}$ The region of Galilee, however, located in modernday northern Israel, has usually been considered atypical to the representation of ancient life described above. This is because Galilee's population was, during the first centuries of our era, largely Jewish and, therefore, in light of the Biblical prohibition, hesitant about conforming easily to a behaviour of displaying (potentially) idolatrous images. ${ }^{4}$ To be sure, evidence of figurative depictions on civic coinage from Sepphoris and Tiberias, the region's two major centres, and on mosaics found in some of the peristyle houses and synagogues, as well as on a variety of other materials, has in recent years received much renewed attention.

1 All dates are CE unless otherwise indicated.

2 Lea M. Stirling, 'Collections, Canons, and Context: The Afterlife of Greek Masterpieces in Late Antiquity', in Using Images in Late Antiquity, Stine Birk, Troels M. Kristensen and Birte Poulsen (eds) (Oxford: Oxbow, 2014): 96.

3 For similar statements, see Yaron Z. Eliav, 'Viewing the Sculptural Environment: Shaping the Second Commandment', in The Talmud Yerushalmi and Graeco-Roman Culture III, Peter Schäfer (ed.) (TSAJ 93; Tübingen: Mohr Siebeck, 2002): 413-4; Peter Stewart, Statues in Roman Society: Representation and Response (Oxford: Oxford University Press, 2003): 6; Mark A. Chancey, Greco-Roman Culture and the Galilee of Jesus (SNTS 134; Cambridge: Cambridge University Press, 2005): 204; Ine Jacobs 'Production to Destruction? Pagan and Mythological Statuary in Asia Minor', AJA 114 (2010): 267.

4 Exod 20:2-5; Deut 5:6-9. For discussion of the Biblical prohibition and the later rabbinic attitudes, see also Steven Fine, 'Iconoclasm and the Art of Late-Antique Palestinian Synagogues', in From Dura to Sepphoris: Studies in Jewish Art and Society in Late Antiquity, Lee I. Levine and Zeev Weiss (eds) (JRASup 14; Portsmouth: JRA, 2000): 186-7; Eliav, 'Viewing the Sculptural Environment': 417-19. 
It has also revised, to some extent, our ideas about Jewish attitudes towards the visual. ${ }^{5}$ The acknowledgement that figurative art was present and known within Jewish society in Galilee has so far, however, not been widely claimed for the field of statuary. In fact, the existence of statuary in Galilee's urban centres is often considered to be minimal at best. As Mark Chancey wrote: '[s]tatues appear to have been rare there . . . for the entire Roman era. ${ }^{6}$ This and other statements rest upon the little - but clearly not absent ${ }^{7}$ - evidence of sculptural decoration that has been found in excavations across Galilee.

The idea of Galilee being a region that during the second to third centuries the prime period of marble import into Palestine ${ }^{8}$ - was principally vacant of

5 For example: Eliav 'Viewing the Sculptural Environment'; Steven Fine, Art and Judaism in the Greco-Roman World: Toward a New Jewish Archaeology (Cambridge: Cambridge University Press, 2005); Lee I. Levine, Visual Judaism in Late Antiquity: Historical Contexts of Jewish Art (New Haven: Yale University Press, 2012).

6 Chancey, Greco-Roman Culture: 210. For a broadly identical statement, see also Zeev Weiss, 'GrecoRoman Influences on the Art and Architecture of the Jewish City in Roman Palestine', in Religious and Ethnic Communities in Later Roman Palestine, Hayim Lapin (ed.) (STJHC 5; Bethesda: University Press of Maryland, 1998): 244-5; 'Sculptures and Sculptural Images in Urban Galilee', in The Sculptural Environment of the Roman Near East: Reflections on Culture, Ideology, and Power, Yaron Z. Eliav, Elise A. Friedland and Sharon C. Herbert (eds) (ISACR 9; Leuven: Peeters, 2008): 573. On the other hand, Eliav ('Viewing the Sculptural Environment': 414-15) claims that, rather than as a result of socio-religious concerns, the number of statues in Palestine was substantially more modest than in other provinces because of the region's political and economic inferiority.

7 For evidence of freestanding statuary at Sepphoris (including fragments of six individual, marble statues and statuettes) and Tiberias, see Weiss, 'Greco-Roman Influences': 244-5; 'Sculptures and Sculptural Images'. In addition to the evidence reported by Weiss, an unknown number of marble sculptural fragments were found in the area of the 'Eastern Basilical Building' (James F. Strange, Thomas R. W. Longstaff and Dennis E. Groh, 'Zippori - 1991', ESI 13 [1994]: 30). Note, in addition, the evidence of a bronze statuette of a winged-male figure, identified as Cupid, at Tiberias (Moshe Hartal, 'Tiberias, Galei Kinneret', HA/ESI 120 [2008], available online at http://www.hadashot-esi. org.il/report_detail_eng.asp?id=773\&mag_id=114), accessed 28 September 2015. Finally, a marble and a limestone foot were found in a cistern in Nazareth dating to the Crusader period (Bellarmino Bagatti, Gli Scavi di Nazaret, Volume I: Dalle Origini al Secolo XII [SBF 17; Jerusalem: Franciscan printing press, 1967): 305-306. The excavator supposes that the two life-size statues to which the feet belonged were originally set up in Tiberias or Caesarea Maritima, but Sepphoris is equally possible. A building inscription from Sepphoris, dated to 517-18, mentions the existence of imperial statues in a civic basilica there (SEG XX 417; XXVI 1667; XLVI 1931). For evidence of a marble head of a female figure originally said to have come from Beth She' arim, see below, n. 50. Furthermore, an unidentified statue was found at Khilf-Tabash (Ariel Berman, 'Lower Galilee and Jezreel Valley Reports', ESI 7-8 [1988]: 200) and the reused bust of a soldier with a cap of Phrygian-type at Magdala (Virgilio Corbo, 'Piazza e Villa Urbana a Magdala', Liber Annuus 28, 1978): 235. In Rome, a statue of a female figure, possibly a personification of Tiberias (Hygieia?), was dedicated by a Tiberian named Ismenos, son of Ienos, to the Tiberian statio there (IGUR 1.83). Cf. Chancey, Greco-Roman Culture: 205, who erroneously describes Tiberias as this statue's findspot.

8 See Moshe L. Fischer, Marble Studies: Roman Palestine and the Marble Trade (Xenia 40; Konstanz: Universitätsverlag Konstanz, 1998): 40-41, 233; Lorenzo Lazzarini, 'La determinazione della provenienza delle pietre decorative usate dai Romani', in I marmi colorati della Roma Imperiale, Marilda De Nuccio and Lucrezia Ungaro (eds) (Venice: Marsilio, 2002): 246; 'La diffusione e il riuso dei più importanti marmi Romani nelle province Imperiali', in Pietre e Marmi Antichi: natura, caratterizzazione, origine, storia d'uso, diffusione, collezionismo, Lorenzo Lazzarini (ed.) (Padua: CEDAM, 2004): 108. 
freestanding statues should, however, be reconsidered. The absence of statuary in Galilee dating to that period, as will be argued in this chapter, could to some extent be a result of the reuse of marble fragments in later limekilns. That much, if not most, of the marble sculpture and architectural elements that once adorned the cities of the Roman East was thrown into such limekilns is generally viewed by scholars as the main reason why so little of this material has survived. ${ }^{9}$ As evidenced by their location at such sites as Bosra, Gerasa, Scythopolis and Sardis, these limekilns were usually installed in the ruins of, or set up nearby, the monumental buildings of those cities. ${ }^{10}$ That the marble sculpture and architecture of

9 For example: Niels Hannestad, Tradition in Late Antique Sculpture: Conservation-ModernizationProduction (Aarhus: Aarhus University Press, 1994): 151; Stewart, Statues in Roman Society: 175; Jacobs, 'Production to Destruction?': 291. But limekilns were, of course, not the only devices destroying ancient statues. Sculpture made of precious metals, such as bronze, was probably more common, but was also more easily melted down for other uses because of the higher scrap value. See Jakob M. Højte, Roman Imperial Statue Bases: From Augustus to Commodus (ASMA 7; Aarhus: Aarhus University Press, 2005): 14, 47-8.

10 Bosra, East Cathedral: Pierre-Marie Blanc, Jean-Marie Dentzer and Jean-Pierre Sodini, 'La Grande Église à Plan Centré (ou 'Cathédrale de l'Est”)', in Bosra: Aux Portes de l'Arabie, Jacqueline Dentzer-Feydy, Michèle Vallerin, Thibaud Fournet, Ryad Mukdad and Anas Mukdad (eds) (Beirut: Presses de 1'institut français du Proche-Orient, 2007): 146; Gerasa, macellum: Alexandra Uscatescu and Manuel Martín-Bueno, 'The Macellum of Gerasa (Jerash, Jordan): From a Market Place to an Industrial Area', BASOR 307 (1997): 78, 81; Hippodrome: Antoni A. Ostrasz, 'The Hippodrome of Gerasa: A Report on Excavations and Research 1982-1987', Syria 66 (1989): 55, 75 n. 29; Scythopolis, West Bathhouse: Gabriel Mazor, 'Beth She'an Project: City Center of Ancient Beth She' an (South)', ESI 6 (1988): 11; 'Beth She' an Project 1988: Department of Antiquities Expedition', ESI 7-8 (1989): 22; Sardis, bath-gymnasium: George M. A. Hanfmann and Nancy H. Ramage, Sculpture From Sardis: The Finds through 1975 (AES 2; Cambridge, MA: Harvard University Press, 1978): 81; Fikret Yegül, The BathGymnasium Complex at Sardis (AES 3; Cambridge, MA: Harvard University Press, 1986): 15-16, 89-93, Fig. 262; Temple of Artemis: Howard C. Butler, Sardis, Vol. I: The Excavations, pt. 1: 1910-1914 (Leiden: Brill, 1922): 28, 74; Sardis, Vol. II: Architecture, pt. 1: the Temple of Artemis (Leiden: Brill, 1925): 10, 13. For limekilns in other cities in the East, see Caesarea Maritima, Vaults below Temple Platform/Warehouses in Area CC: Yosef Porath, 'The Caesarea Excavation Project - March 1992-June 1994: Expedition of the Antiquities Authority', ESI 17 (1998): 47; Gadara, Five-aisled Basilica: Thomas Weber and Ulrich Hübner, 'Gadara 1998: The Excavation of the Five-aisled Basilica at Umm Qays: A Preliminary Report', ADAJ 42 (1998): 449; Philadelphia, Temple of Hercules: Ignacio Arce, 'Early Islamic Lime Kilns from the Near East: The Cases from Amman Citadel', in Proceedings of the First International Congress on Construction History, Madrid, 20th-24th January 2003, S. Huerta (ed.) (Madrid: I. Juan de Herrera, 2003): 214-18, 221-2; Palmyra, Sanctuary of Allat: Michal Gawlikowski, 'Excavations in the Allat Sanctuary, 2005-2006', PAM 18 (2008): 535-6; Apamea, Long Hall/Agora: Clive Foss, 'Syria in Transition, A.D. 550-750: An Archaeological Approach', DOP 51 (1997): 209-10; Baths: Hannestad, Tradition in Late Antique Sculpture: 151, n. 254; Antioch, Bath C: George W. Elderkin (ed.), Antioch-on-the-Orontes I. The Excavations of 1932 (Princeton: Princeton University Press, 1934): 19-31; House of the Calendar: Princeton University, Research Photographs: Antioch Photo Archive, no. 1977, available online athttp://www.princeton.edu/researchphotographs/archaeological-archives/antioch/, accessed 28 September 2015; Ephesus, Temple of Artemis: Clive Foss, Ephesus after Antiquity (Cambridge: Cambridge University Press, 1979): 87; Byzantine Palace: Andreas Pülz, 'Ephesos in Spätantiker und 
these former monuments was used to feed these limekilns is suggested both by the discovery of marble near these kilns ${ }^{11}$ and by numerous travel accounts attesting to such practices among the local population during the nineteenth century. ${ }^{12}$ Indeed, there is abundant evidence suggesting that much of the marble of the cities of the Roman Levant eventually ended up in limekilns to be reused in the later building industry. ${ }^{13}$ Therefore, the contrast between urban Galilee and other areas of the Levant was not necessarily as great as some scholars tend to suggest, and the habit of setting up statuary in Galilee may not be so different to that in surrounding regions. ${ }^{14}$ In any case, evidence for reusing marble sculpture and architectural elements in Galilean limekilns requires us, at least, to nuance the idea that the region was devoid of freestanding statues.

Ancient limekilns, however, have remained at the margins of scholarship in general. Not only is the evidence for limekilns at archaeological sites across the Roman Empire often poorly reported, but their place and role within the society of that time is also something that is not generally discussed..$^{15}$ Indeed, scholars only show a faint interest in the societal and economic motives behind the appearance of urban limekilns during Late Antiquity and later, but instead view them as ferocious villains that

Byzantinischer Zeit', FA 53/XII (2009), available online at http://farch.net, accessed 25 January 2016; Pergamon, City Excavations: Wolfgang Radt, 'Pergamon, 1986', AS 37 (1987): 212-13. For discussion of limekilns that is more focused on the Western provinces, see Beth Munro, 'Sculptural Deposition and Lime Kilns at Roman Villas in Italy and the Western Provinces in Late Antiquity', in The Afterlife of Greek and Roman Sculpture: Late Antique Responses and Practices, Troels M. Kristensen and Lea M. Stirling (eds) (Ann Arbor: University of Michigan Press, forthcoming).

11 For example, Pergamon (Radt, 'Pergamon': 213), Ptolemais (in Cyrenaica) (Karl H. Kraeling, Ptolemais: City of The Libyan Pentapolis (Chicago: The University of Chicago Press, 1962): 148, 163, 168, 170), Sardis (Hanfmann and Ramage, Sculpture from Sardis: 81). At all three sites a substantial number of partly burned sculptural fragments were found near the limekilns.

12 For such travel accounts, see Michael Greenhalgh, Constantinople to Córdoba: Dismantling Ancient Architecture in the East, North Africa and Islamic Spain (Leiden: Brill, 2012): 56-60; From the Romans to the Railways: The Fate of Antiquities in Asia Minor (Technology and Change in History 13; Leiden: Brill, 2013): 134-6. One salient example forms the account of the German civil engineer Carl Humann, who in the mid-1860s alarmingly observed how the local population was feeding the remnants of the Great Altar of Pergamon to the limekilns.

13 For a similar observation, see Hannestad, Tradition in Late Antique Sculpture: 151 and n. 254.

14 As suggested by some recent datasets, when compared to neighbouring regions of the Empire (North Africa, Asia Minor), the Levant in general seems to have remained rather devoid of statues at least those of life-size. Cf. Højte, Roman Imperial Statue Bases, especially p. 629 for statue bases from the first and second centuries and University of Oxford, Last Statues of Antiquity Database, available online at http://laststatues.classics.ox.ac.uk/, accessed 28 September 2015, for evidence of statues set up after 284. Note, however, that this observation remains tentative as both datasets, for obvious reasons, remain incomplete.

15 Brigitte Demierre, 'Les Fours à Chaux en Grèce', JRA 15 (2002): 283; Anna Leone, The End of the Pagan City: Religion, Economy, and Urbanism in Late Antique North Africa (Oxford: Oxford University Press, 2013): 153; Munro, 'Sculptural Deposition'. A case in point is the recent, threevolume work The Economic History of Byzantium (Angeliki E. Laiou (ed.), DOP 39; Washington, DC: Dumbarton Oaks, 2002) that, aside from two rare instances at Anemourion and Sardis, leaves the topic of limekilns completely undiscussed. 
are partly to blame for the ruinous and incomplete state of the classical landscape we have inherited. With the rise of scholarly interest in late antique society in general, however, changes in the attitude towards limekilns are becoming more apparent. ${ }^{16}$ This chapter is in part an attempt to contribute to this growing movement which seeks to understand the role of urban limekilns in Late Antiquity and later.

\section{Limekilns and the Production of Lime}

While in earlier times lime was produced and used only on a limited scale, from the Roman period onwards it became a highly desired product. ${ }^{17}$ The main reason for this is the importance of lime for the construction industry, for the production of such bonding material as mortar and concrete, as well as of plaster and stucco. ${ }^{18}$

In order to produce lime, limestone blocks first had to be heated in a kiln specifically built for this purpose to a temperature of $900-1100^{\circ} \mathrm{C}$, depending on which stone-type was used, for a prolonged period of time. This process is called calcination. The duration of heating and subsequent cooling of a full limekiln could in antiquity easily take up to as long as one to two weeks. Also taking into account time for loading and unloading, the entire production process would have taken as long as two to three weeks. ${ }^{19}$ The resulting product after the limestone blocks have been heated in the kiln is calcium oxide, or 'quicklime'. ${ }^{20}$ After calcination, the limestone blocks retained their original shape but became more crumbly and lost half their weight. ${ }^{21}$

For its use in the construction industry, however, the crumbly quicklime still needed to be decomposed by hydration, or slaking, to become a bonding agent, or 'slaked lime'. The resulting lime putty would then form the base to which sand and other materials (e.g. crushed tiles and potsherds) were added to create mortar and plaster. The slaking process of the lime was usually done in a pit dug close to the limekiln, from where it was eventually transported to the construction site, or at the construction site itself. ${ }^{22}$

16 See Demierre, 'Les Fours à Chaux en Grèce'; Anna Leone, Changing Townscapes in North Africa From Late Antiquity to the Arab Conquest (Bari: Edipuglia, 2007): 213-17; Munro, 'Sculptural Deposition'.

17 Brian Dix, 'The Manufacture of Lime and Its Uses in the Western Roman Provinces', OJA 1 (1982): 339-40; Jean-Pierre Adam, Roman Building: Materials and Techniques (London: Routledge, 1994): 116.

18 See Dix, 'The Manufacture of Lime': 341-2 with further references to ancient sources. Lime was also used as a fertilizer in agriculture, as well as for other purposes (for example, tanning and medicine).

19 Dix, 'The Manufacture of Lime': 335-6. For the duration of the heating process of some modern limekilns, see Adam, Roman Building: 123-4.

20 Dix, 'The Manufacture of Lime': 331; Adam, Roman Building: 116-17.

21 Dix, 'The Manufacture of Lime': 336. Cf. Vitruvius, Arch., 2, 5.3.

22 Roger Ling, 'Stuccowork', in Roman Crafts, Donald Strong and David Brown (eds) (London: Duckworth, 1976): 210-12; Dix, 'The Manufacture of Lime': 337-9; Adam, Roman Building: 127-9. 


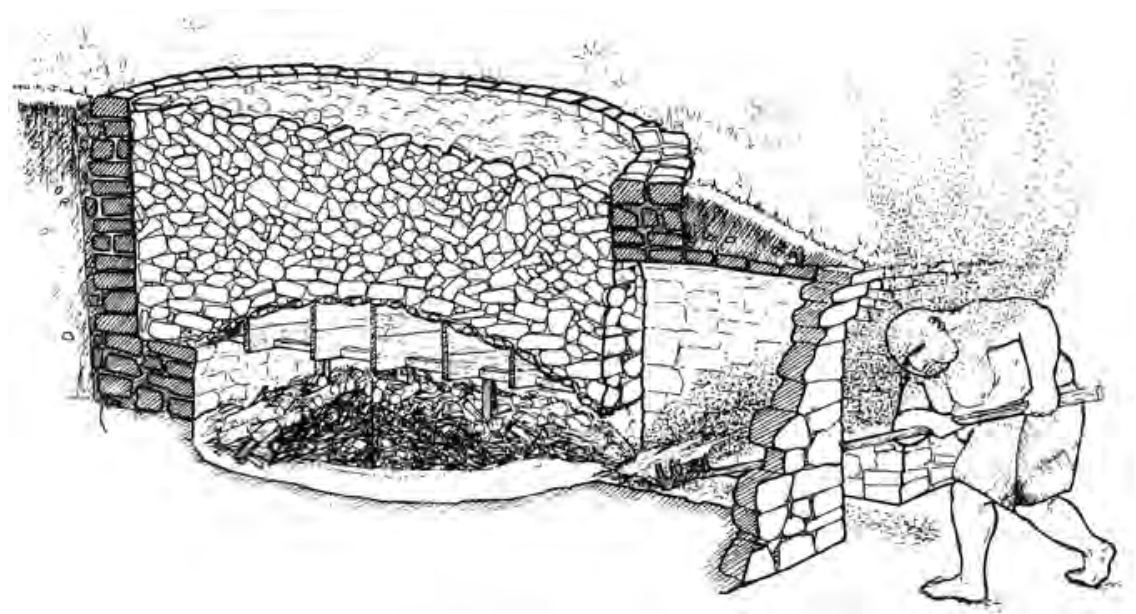

Figure 10.1 Reconstruction of a limekiln ready for firing (after Dix, 'The Manufacture of Lime', Fig. 2, courtesy of Brian F. Dix)

As described already by Cato the Elder around $160 \mathrm{BCE}$, for the calcination of lime the ancients used mainly periodic, or 'flare' kilns, in which lime was produced by radiant heat (Fig. 10.1). ${ }^{23}$ These kilns were circular in shape and measured 2-7 $\mathrm{m}$ in diameter, while their height would usually have been a little less. ${ }^{24}$ The upper part of these kilns resembled a truncated cone. It would be set either in a specially quarried pit or into a hillside slope. The latter position was favoured because it produced a more constant temperature and provided easy access to the kiln's lower part for the fire and its upper part for the loading and unloading of the limestone blocks. ${ }^{25}$ Finally, limekilns usually had one or two stokeholes for fuelling and ventilation purposes.

For the production of lime, ancient craftsmen appear to have favoured white limestone and marble above other types of stone, mainly because of the few impurities that these stones have. ${ }^{26}$ For instance, in Late Republican times, Cato the Elder pointed out that a white, uniform stone is the best material for such purpose. ${ }^{27}$ The fifth century author Palladius also acknowledged the use of marble,

23 Cato, Agr., 38. See also Dix, 'The Manufacture of Lime': 332-3.

24 Dix, 'The Manufacture of Lime': 333; Adam, Roman Building: 119.

25 Adam, Roman Building: 119.

26 Ling, 'Stuccowork': 210; Dix, 'The Manufacture of Lime': 334; Michael Greenhalgh, The Survival of Roman Antiquities in the Middle Ages (London: Duckworth, 1989): 206; Constantinople to Córdoba: 59; Munro, 'Sculptural Deposition'.

27 Cato, Agr., 38. See also Pliny the Elder, Hist. nat., 36, 53, who repeats Cato the Elder's statement. 
among other stones, as a suitable material for lime production. ${ }^{28}$ Vitruvius provided a further functional distinction between limestones of a harder texture and the more porous ones; the former being more suited as a mortar for wall construction, while the latter was better for plastering. ${ }^{29}$

Because of the weight of the stone, the proximity to its source material was a key factor in the location of limekilns. Another factor determining their location was the availability of sufficient fuel. For these reasons limekilns were, in antiquity, usually situated as near as possible to limestone quarries, at some distance from the settlements where the large building projects took place. ${ }^{30}$ However, in certain instances, limekilns were set up within settlements because of the nearness of sufficient building material that could be reused as well as the proximity of the construction site. For example, a limekiln that was exposed in the House of the Iliac Chapel in Pompeii was apparently used to rebuild this neighbourhood after the earthquake of $62 .{ }^{31}$ With more and more limestone and marble material of gradually abandoned monuments lying around in urban contexts and available for recycling, the placement of limekilns in such contexts became a relatively common phenomenon from Late Antiquity onwards. This holds true both for the western and the eastern provinces of the Empire, including the region of Galilee.

Table 10.1 Limekilns and associated evidence in Galilee, alphabetically ordered

\begin{tabular}{|c|c|c|c|c|}
\hline No. & Site & Type of evidence & Location & Date \\
\hline 1 & Beth She arim $^{32}$ & $\begin{array}{l}\text { Deposit of broken marble } \\
\text { sarcophagi }\end{array}$ & $\begin{array}{l}\text { Catacomb no. 20, } \\
\text { mainly in its } \\
\text { central hall }\end{array}$ & $\begin{array}{l}\text { Late Byzantine/ } \\
\text { Early } \\
\text { Islamic(?) }\end{array}$ \\
\hline 2 & Beth She arim $^{33}$ & $\begin{array}{l}\text { Deposit of broken marble } \\
\text { revetment and lime }\end{array}$ & $\begin{array}{l}\text { Near one of the } \\
\text { exterior walls of a } \\
\text { basilical building }\end{array}$ & - \\
\hline 3 & Beth She arim $^{34}$ & $\begin{array}{l}\text { Deposit of broken } \\
\text { marble revetment and } \\
\text { inscribed slabs }\end{array}$ & $\begin{array}{l}\text { Spread around } \\
\text { the synagogue } \\
\text { and adjoining } \\
\text { buildings }\end{array}$ & - \\
\hline
\end{tabular}

28 Palladius, Op. agr., 1, 10.3.

29 Vitruvius, Arch., 2, 5.1.

30 Dix, 'The Manufacture of Lime': 337; Adam, Roman Building: 126; Munro, 'Sculptural Deposition'.

31 Adam, Roman Building: 127-8.

32 Nahman Avigad, Beth She arim III: Report on the Excavations during 1953-1958: Catacombs 12-23 (Brunswick: Rutgers University Press, 1976): 93-115, 164-5.

33 Benjamin Mazar, 'Beth She arim', IEJ 6 (1956): 261; Nahman Avigad, 'Excavations at Beth She arim, 1955: Preliminary Report', IEJ 7 (1957): 75.

34 Benjamin Mazar, 'Excavations in Palestine and Trans-Jordan - Esh Sheikh Ibreiq', QDAP (1941): 213; Beth She arim I: Report on the Excavations during 1936-1940: Catacombs 1-4 (Brunswick: Rutgers University Press, 1973): 18; Moshe Schwabe and Baruch Lifshitz, Beth She 'arim II: The Greek Inscriptions (Brunswick: Rutgers University Press, 1974): 189-98, pl. VII, 2-5. 
4 H. 'Ammudim ${ }^{35}$ Limekiln(?)

5 Kh. en-Nabrah ${ }^{36}$ Limekiln + deposit of

$6 \quad$ Kh. Shifat ${ }^{37} \quad$ Limekiln(?)

7 Meiron $^{38} \quad$ Limekiln

8 Meiron $^{39}$

Deposit of slaked lime

9

10 Sepphoris $^{41}$
Limekiln

Limekiln + deposit of marble fragments
$-$

$-$

North of the settlement

North of a terrace wall, c. $40 \mathrm{~m}$ northeast of synagogue Unidentified structure, $c .40 \mathrm{~m}$ west of synagogue

Several metres east of synagogue

Near the Cardo, north of the 'Eastern Basilical Building'
Modern(?)

11th-14th century

Mameluke

Modern(?)

$\geq$ Byzantine

(continued)

35 Eliot Braun, 'Soundings at Horbat 'Ammudim, Lower Galilee', 'Atiqot 42 (2001): 238; Uzi Leibner, Settlement and History in Hellenistic, Roman and Byzantine Galilee: An Archaeological Survey of the Eastern Galilee (TSAJ 127; Tübingen: Mohr Siebeck, 2009): 243. Leibner probably identified the circular structure that was earlier exposed by Braun as a limekiln. Yet, while the shape and size of this feature indeed match those of a limekiln, it should be noted that Braun did not at the time of his discovery identify it as such.

36 Victor M. Guérin, Description Géographique, Historique et Archéologique de la Palestine, III Galilée (Paris: L'Imprimerie Nationale, 1880): 441; Claude R. Conder and Horatio H. Kitchener, The Survey of Western Palestine. Memoirs of the Topography, Orography, Hydrography, and Archaeology: Volume I, Sheets I-VI, Galilee (London: Palestine Exploration Fund, 1881): 243; Ernest W. G. Masterman, Studies in Galilee (Chicago: The University of Chicago Press, 1909): 121; Eric M. Meyers, James F. Strange, Carol L. Meyers and Joyce Raynor, 'Preliminary Report on the 1980 Excavations at en-Nabratein, Israel', BASOR 244 (1981): 3; Eric M. Meyers and Carol L. Meyers, Excavations at Ancient Nabratein: Synagogue and Environs (MEPR 6; Winona Lake: American Schools of Oriental Research, 2009): 2, 15.

37 Rafer Abu Raya and Anastasia Shapiro, 'Yodefat, Survey', HA/ESI 123 (2011), 2015, available online at http://www.hadashot-esi.org.il/report_detail_eng.aspx?id=1838\&mag_id=118, accessed 28 September.

38 Meyers et al., Excavations at Ancient Meiron: 20-22; James F. Strange, pers. comm.

39 Eric M. Meyers and Dan Barag, 'Meiron', in Encyclopedia of Archaeological Excavations in the Holy Land III, Michael Avi-Yonah (ed.) (Oxford: Oxford University Press, 1977): 860 (terrace wall mistakenly described as a fortification tower, and the limekiln's dimensions are mistaken); Eric M. Meyers, James F. Strange and Carol L. Meyers, Excavations at Ancient Meiron, Upper Galilee, Israel, 1971-72, 1974-75, 1977 (MEPR 3; Cambridge, MA: American Schools of Oriental Research, 1981): 87, Figs 4.8 and 4.10.

40 Eric M. Meyers, James F. Strange and Dennis E. Groh, 'The Meiron Excavation Project: Archaeological Survey in Galilee and Golan, 1976', BASOR 230 (1978): Fig. 2 (mistakenly described as a 'pool'); Meyers et al., 'Preliminary Report on the 1980 Excavations at en-Nabratein, Israel': 5, 7; Meyers and Meyers, Excavations at Ancient Nabratein: 23.

41 Zeev Weiss and Ehud Netzer, 'Zippori - 1992/1993', ESI 14 (1995): 45; 'Zippori - 1994-1995', ESI 18 (1998): 24; Zeev Weiss, pers. comm. 
Table 10.1 (continued)

\begin{tabular}{|c|c|c|c|c|}
\hline No. & Site & Type of evidence & Location & Date \\
\hline 11 & Sepphoris ${ }^{42}$ & $\begin{array}{l}\text { Two limekilns }+ \text { deposit } \\
\text { of marble fragments }\end{array}$ & $\begin{array}{l}\text { East side of the } \\
\text { 'Eastern Basilical } \\
\text { Building' }\end{array}$ & $\geq$ Byzantine \\
\hline 12 & Sepphoris $^{43}$ & $\begin{array}{l}\text { Limekiln + deposit } \\
\text { of architectural } \\
\text { fragments, incl. marble }\end{array}$ & $\begin{array}{l}\text { Southern row of } \\
\text { shops along the } \\
\text { Decumanus }\end{array}$ & $\geq$ Late Byzantine \\
\hline 13 & Sepphoris $^{44}$ & Limekiln & $\begin{array}{l}\text { South side of the } \\
\text { House of Dionysos }\end{array}$ & $\geq$ Byzantine \\
\hline 14 & Sepphoris $^{45}$ & $\begin{array}{l}\text { Limekiln + deposit } \\
\text { of architectural (marble?) } \\
\text { fragments }\end{array}$ & $\begin{array}{l}\text { East of the theatre's } \\
\text { stage area }\end{array}$ & Byzantine(?) \\
\hline 15 & Sepphoris $^{46}$ & Limekiln & $\begin{array}{l}\text { Northwest corner of } \\
\text { 'Unit VII' }\end{array}$ & $\begin{array}{l}\geq \text { Late } \\
\text { Byzantine; } \\
\text { excavators } \\
\text { assume a } \\
\text { Crusader date }\end{array}$ \\
\hline 16 & Sepphoris ${ }^{47}$ & $\begin{array}{l}\text { Deposit of broken } \\
\text { marble revetment }\end{array}$ & $\begin{array}{l}\text { Southwest area of } \\
\text { 'The Villa' }\end{array}$ & $\geq 4$ th century \\
\hline 17 & Tarshiha $^{48}$ & Limekiln & $\begin{array}{l}\text { North of modern } \\
\text { village }\end{array}$ & - \\
\hline
\end{tabular}

\section{The Lime Industry in Galilee}

At least thirteen limekilns and ten associated deposits have been discovered so far in Galilee (Table 10.1). The period in which these limekilns were in use ranges from the Byzantine period up to early modern times.

42 Strange et al., 'Zippori-1991': 30; C. Thomas McCollough, 'Monumental Changes: Architecture and Culture in Late Roman and Early Byzantine Sepphoris', in The Archaeology of Difference: Gender, Ethnicity, Class and the 'Other' in Antiquity: Studies in Honor of Eric M. Meyers, Douglas R. Edwards and C. Thomas McCollough (eds) (AASOR 60/61; Boston: American Schools of Oriental Research, 2007): 273; James F. Strange, pers. comm.

43 Zeev Weiss, 'Sepphoris (Sippori): 2005', IEJ 55 (2005): Figs 1-2 and 224; 'Sepphoris (Sippori): 2007', IEJ 57 (2007): Fig. 5; 'From Roman Temple to Byzantine Church: A Preliminary Report on Sepphoris in Transition', JRA 23 (2010): 214.

44 Weiss and Netzer, 'Zippori - 1992/1993': 41; Zeev Weiss, pers. comm.

45 Leroy Waterman (ed.), Preliminary Report of the University of Michigan Excavations at Sepphoris, Palestine, in 1931 (Ann Arbor: University of Michigan Press, 1937): 11 and pl. XVIII, Fig. 2; Zeev Weiss and Ehud Netzer, 'Sepphoris during the Byzantine Period', in Sepphoris in Galilee: Crosscurrents of Culture, Rebecca M. Nagy, Carol L. Meyers, Eric M. Meyers and Zeev Weiss (eds) (Winona Lake: Eisenbrauns, 1996): 82; Alysia Fischer, Hot Pursuit: Integrating Anthropology in Search of Ancient Glass-Blowers (Lanham: Lexington Books, 2008): 48-9.

46 Byron R. McCane, pers. comm.

47 James F. Strange, Thomas R. W. Longstaff and Dennis E. Groh, Excavations at Sepphoris, Volume I: University of South Florida Probes in the Citadel and Villa (BRLJ 22; Leiden: Brill, 2006 ): 87.

48 Yoav Lerer, 'Tarshiha, Survey', HA/ESI 123 (2011), http://www.hadashot-esi.org.il/report_detail_ eng.aspx?id=1689\&mag_id=118, accessed 28 September 2015. 
A first point to be noted is that no date is known for those circular features exposed in rural Galilee of which the identification as a limekiln remains uncertain, such as Horvat 'Ammudim, Khirbet Shifat and Tarshiha (Table 10.1:4, 6, 17). On the other hand, the securely identified circular limekilns from rural Galilee were all constructed relatively late, around the Late Islamic period or later. For example, in the second half of the nineteenth century, the French explorer V. Guérin noticed a limekiln at the small hilltop site of Khirbet en-Nabrah (Table 10.1:5), located $c$. $250 \mathrm{~m}$ south of Nabratein, around which a considerable number of architectural fragments were gathered for burning. Whether it was still in use at the time of Guérin's visit is not entirely clear from his description, but it remains a possibility. The best-dated limekiln is found at Meiron, in northern Galilee, and is located to the southeast of the late-antique synagogue (Table 10.1:7). It was dated on the basis of stratigraphic finds to the Late Islamic period. To the southwest of this limekiln, c. 60 m uphill, a deposit of slaked lime was discovered in an unidentified structure from the Mameluke period (Table 10.1:8). Considering their proximity in location and date, it is very possible that the two features are related to one another.

Besides the relatively late date of the limekilns in rural Galilee, another notable feature is that only local limestone appears to have been used for the production of lime. This supports Moshe Fischer's earlier argument that the population living in the more remote, rural areas of Palestine chiefly relied on local limestone for producing lime, despite its inferiority to marble as a source. ${ }^{49}$ The reason for this preference was purely practical. The limestone construction material from former local buildings was more easily available to them than the marble remains lying around the relatively distant, former urban settlements.

Beth She'arim, in southwestern Galilee, is an exception to this however. Although this site was not a major urban centre in antiquity, archaeological explorations at this settlement and its extensive necropolis have exposed a considerable number of fragmentary marble sarcophagi, wall revetment, floor slabs, inscriptions and even a statue (Table 10.1:1-3). ${ }^{50}$ The reason for the abundance of marble there seems to be related to the social importance of its large necropolis, with at least 27 extensive catacombs and several mausolea, to the Jewish community in the region (and, perhaps, even far beyond) during antiquity. ${ }^{51}$ Another reason,

49 Moshe L. Fischer, 'The Fate of Holy Land Marble: Remarks on Recycling in the Past', in Archéomatériaux: Marbres et Autres Roches - Actes de la IV Conférence Internationale ASMOSIA IV, France, Bordeaux-Talence, 9-13 Octobre 1995, Max Schvoerer (ed.) (Bordeaux: Centre de Recherche en Physique Appliquée à l'Archéologie, 1999): 283.

50 In 1872, C. R. Conder and H. H. Kitchener were shown in Nazareth a c. $18 \mathrm{~cm}$ high female head, carved in white marble, that was said to have originated from Beth She'arim. See Conder and Kitchener, The Survey of Western Palestine: 350-51.

51 Inscriptions that were found there demonstrate the burial of certain individuals who were referred to as 'rabbi', as well as of certain individuals who originated from regions beyond Galilee. Based upon this epigraphic evidence in particular, the excavators have argued that after certain members of the rabbinic family were buried there during the third century, Beth She'arim promptly became a central burial site for Jews throughout Palestine and the Diaspora. In more recent years, however, certain scholars have expressed doubts regarding the excavator's original narrative of Beth She 'arim's necropolis as a rabbinic centre where Diaspora Jews wanted to be buried. 
however, was probably its location along an Imperial road leading from the coastal city of Ptolemais, where imported marble would first arrive, to the inland cities of Scythopolis, Gadara, Bosra and Gerasa. While no limekiln has been found so far at Beth She arim, the particular circumstance in which the marble fragments at the site were found suggests that its marble was reused for the production of lime. For example, in the central hall of Catacomb 20, near its entrance, marble fragments of at least 20 sarcophagi, some decorated with mythological scenes, were found (Table 10.1:1). According to the excavator, people began splitting the marble sarcophagi into pieces after the catacombs had gone out of use in order to make the marble suitable for a limekiln and stored the fragments near the catacomb's entrance. From there, these marble fragments were most probably transported to a limekiln. ${ }^{52}$ The excavator suggested that this occurred in the Early Islamic period or somewhat later. Yet, more recently, Fanny Vitto has argued, based on a re-dating of certain finds associated with the thick layer of debris in Catacomb 20, that the splitting of the marble sarcophagi may already have happened as early as the Late Byzantine period. ${ }^{53}$ Other marble deposits at Beth She arim were found in the settlement on top of the hill. A considerable deposit of broken marble slabs and ornaments was found, for instance, near one of the exterior walls of a basilical building, while other marble fragments, including 14 epitaphs that probably derived from the necropolis, were found spread around the settlement's synagogue (Table 10.1:2-3).

Feeding white marble to the limekilns occurred, however, primarily in urban settlements, including those of Galilee, because the structures here were, during

For discussion, see Tessa Rajak 'The Rabbinic Dead and the Diaspora Dead at Beth She 'arim', in The Talmud Yerushalmi and Graeco-Roman Culture I, Peter Schäfer (ed.) (TSAJ 73; Tübingen: Mohr Siebeck, 1998); Lee I. Levine, 'Bet Še 'arim in Its Patriarchal Context', in 'The Words of a Wise Man's Mouth are Gracious' (Qoh 10,12): Festschrift for Günter Stemberger on the Occasion of his $65^{\text {th }}$ Birthday, Mauro Perani (ed.) (SJ 32; Berlin: De Gruyter, 2005).

52 The marble fragments in the central hall were found upon a 20-50 cm layer of debris (Avigad, Beth She arim III: 93). As suggested from the remains of ash, wood, cloth and animal bones in the layer of debris, it is possible that the people who reused the marble sarcophagi also lived there for some time. It is, furthermore, important to note that only the marble was of significance to these later intruders, as they left the approximately 125 limestone sarcophagi in Catacomb 20 intact.

53 Avigad, Beth She 'arim III; Fanny Vitto, 'Byzantine Mosaics at Beth She 'arim: New Evidence for the History of the Site', 'Atiqot 28 (1996). Based on the high lime content of a large glass slab that was also found at Beth She'arim, Vitto ('Byzantine Mosaics': 140-41) suggested furthermore that the lime obtained from the marble sarcophagi was possibly used for the production of ancient glass. However, analysis of the glass slab's composition has determined that its high lime content was a result of mixing plant ash and shell-bearing sand, two lime-rich materials. See Ian C. Freestone and Yael Gorin-Rosen, 'The Great Glass Slab of Bet Shearim: An Early Islamic Glass-Making Experiment?', JGS 41 (1999): 115. Subsequent studies have shown, furthermore, that it was chiefly the shell-bearing sand of the Levantine coastal area that produced the relatively high lime content in the Roman-Byzantine glass produced there. See Ian C. Freestone, K. A. Leslie, M. Thirlwall and Yael Gorin-Rosen, 'Strontium Isotopes in the Investigation of Early Glass Production: Byzantine and Early Islamic Glass from the Near East', Archaeometry 45 (2003): 29-30; Patrick Degryse and Jens Schneider, 'Pliny the Elder and $\mathrm{Sr}-\mathrm{Nd}$ Isotopes: Tracing the Provenance of Raw Materials for Roman Glass Production', JAS 35 (2008): 1997. 


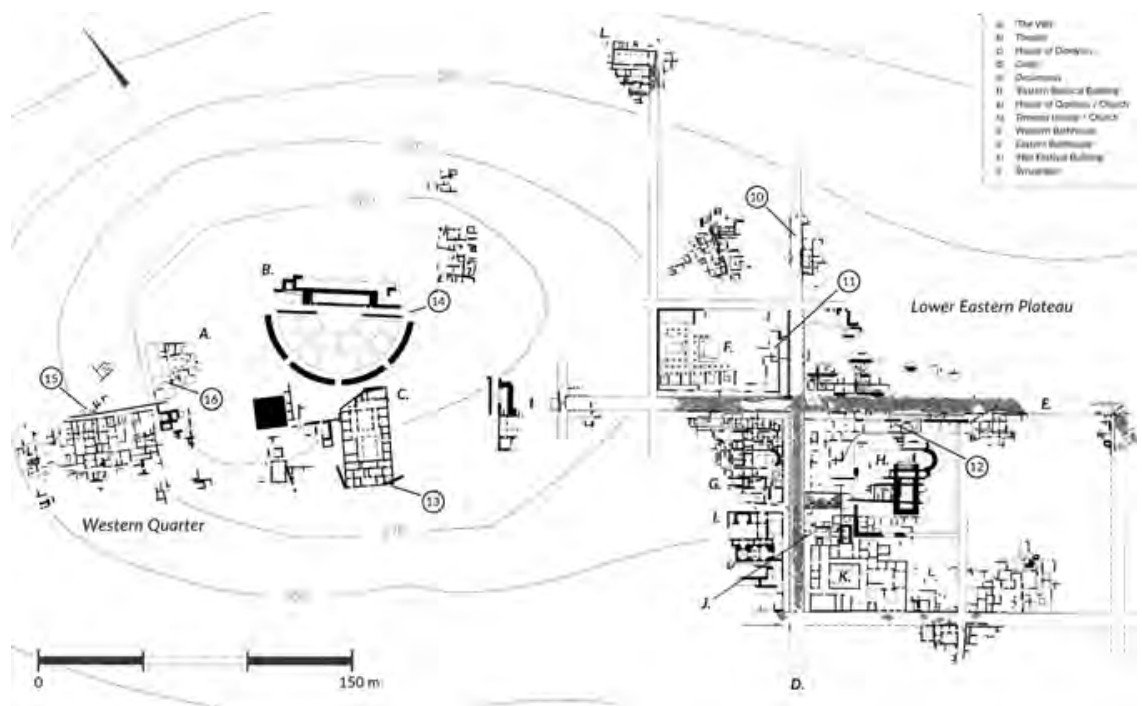

Figure 10.2 Ground plan of Sepphoris. The limekilns are numbered as in Table 10.1 (after Weiss, 'From Roman Temple to Byzantine Church', Fig. 1, courtesy of Zeev Weiss, The Sepphoris Expedition, The Hebrew University of Jerusalem; drawings by Anna Iamim)

antiquity, more richly decorated with marble sculpture and architectural elements. That being said, there is, to my knowledge, no evidence related to a lime industry exposed so far in any excavation in Tiberias. This is probably because of Tiberias' continuous occupation history from its early first century foundation onwards, since this has obliterated much of the earlier remains and hinders systematic archaeological investigations of the city's previous histories. That limekilns were used in Tiberias during Late Antiquity is, however, suggested by the fourthcentury Church Father Epiphanius of Salamis. Epiphanius provides the story of how the Jewish-convert Joseph of Tiberias built a small church in Tiberias upon the ruins of a former temple, the 'Hadrianeion'. ${ }^{54}$ Josephus first required lime in order to build this church and, therefore, constructed seven limekilns along the borders of the city. Considering the fact that material from the former 'Hadrianeion' was being reused, it is reasonable to suggest that these kilns were stacked with marble building elements and statuary belonging to that structure.

For Sepphoris, on the other hand, there is ample archaeological evidence for a late-antique lime industry due to the large-scale excavations at this site. ${ }^{55}$

54 Epiphanius of Salamis, Pan. 30.12, especially 30.12.4.

55 For an overview of the excavations, see Zeev Weiss, 'Sepphoris', in NEAHL 4, Ephraim Stern (ed.) (Jerusalem: Israel Exploration Society, 1993); 'Sepphoris', in NEAHL 5, Ephraim Stern (ed.) (Jerusalem: Israel Exploration Society, 2008). 
So far at least seven limekilns have been exposed (Fig. 10.2), though none is reported in considerable detail. On the Lower Eastern Plateau, one limekiln was exposed to the north of the so-called 'Eastern Basilical Building', near the Cardo (Table 10.1:10). ${ }^{56}$ Nearby, lay a substantial number of marble fragments, including part of a statue that, presumably, was moved there before throwing it into the limekiln. Further southwest, on the eastern grounds of the former 'Eastern Basilical Building', two other limekilns have been found (Table 10.1:11). ${ }^{57}$ Furthermore, related to these limekilns, 'hundreds of marble fragments, including pieces of a screen, Corinthian capitals, [and] statues' were found piled over a corner of the former building. ${ }^{58}$ Another limekiln was found above one of the southern shops aligning the Decumanus, directly north of a fifth century church that was built over the remains of a second century temple complex (Table 10.1:12). Immediately south of this limekiln, and associated with it, lay a large number of architectural fragments, including pieces of broken marble that derived from the church.

Moving west to the hilltop area, in close association to an east-west running, broad wall there, a limekiln was dug into the ruins of the House of Dionysos, which was abandoned by the late fourth century (Table 10.1:13). Another circular limekiln, exposed in 1931 by Leroy Waterman, sat directly east of the stage area of the former theatre (Table 10.1:14; Fig. 10.3). Decorative architecture from the former theatre, either of limestone or marble, lay around next to it. The theatre area 'was [during the Byzantine period] a quarry for stones and raw materials for the lime industry'. ${ }^{59}$ The final limekiln exposed so far at Sepphoris sits in the so-called Western Quarter, built into the ruins of a domestic building (named 'Unit VII') that was in use from the first to the fifth century (Table 10.1:15). Relatively nearby, $c$. $40 \mathrm{~m}$ to the east, a heap of broken marble revetment was found piled in one of the rooms of a former peristyle house (named 'The Villa') after it had fallen in ruins during the fourth century (Table 10.1:16). It is possible that people intended to store the marble here temporarily before it was thrown into the nearest limekiln.

The evidence from Sepphoris (but note also Beth She'arim) makes it particularly clear that the availability of sufficient marble in Galilee's urban areas played an important role when deciding where to set up limekilns. This is evident from the fact that in at least three cases there, possibly four, a heap of broken marble was found very near to some limekilns. Though the reports do not provide much detail, there is explicit evidence at Sepphoris of marble statuary being broken up for reuse in these limekilns, as in the cases of Pergamon, Ptolemais and Sardis. ${ }^{60}$

56 The precise identification of this building is still debated (civic basilica, forum or macellum). For discussion, see Rick Bonnie, 'Galilee during the Second Century AD: An Archaeological Examination of a Period of Socio-Cultural Development', (PhD dissertation; KU Leuven, 2014): 110-20.

57 Only one limekiln was reported in excavation reports of this area (McCollough, 'Monumental Changes': 273). However, in a personal communication, James F. Strange, the director of the excavations, noted a second limekiln there.

58 Strange et al., 'Zippori - 1991': 30.

59 Weiss, 'Sepphoris', NEAEHL 4, 1327.

60 See above, n. 11. 


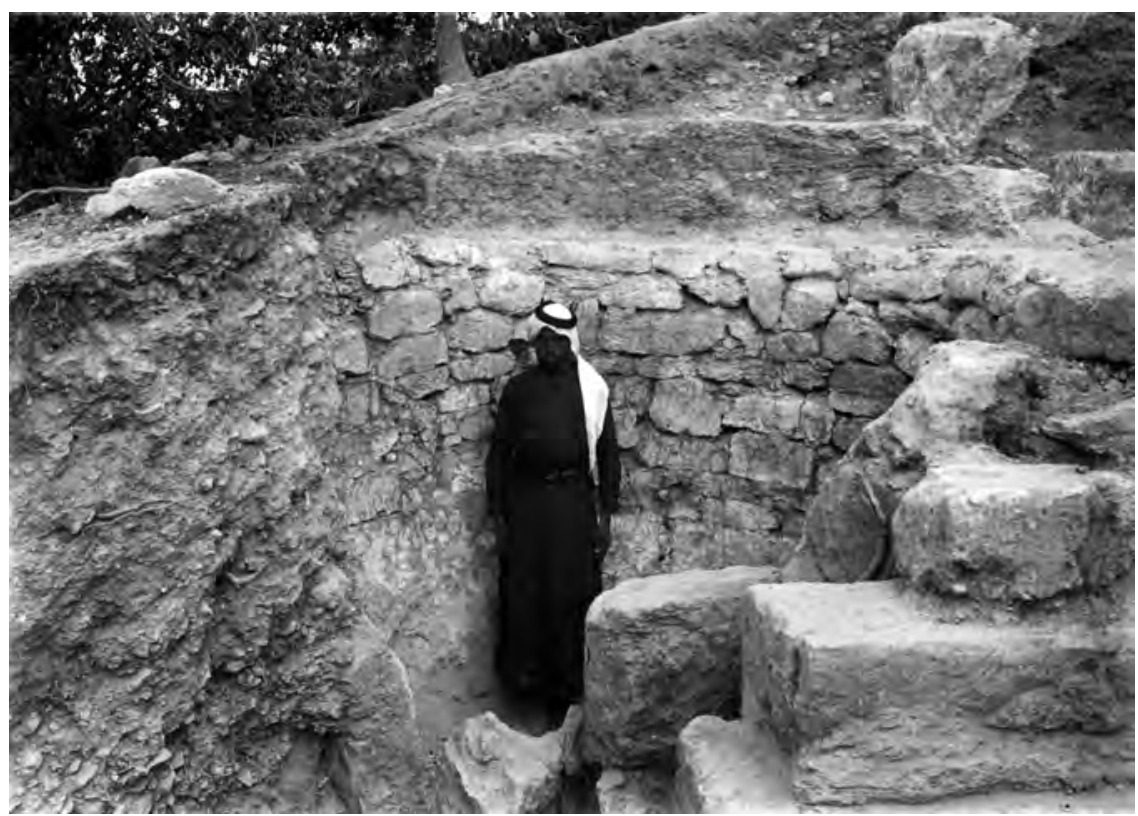

Figure 10.3 Sepphoris, circular limekiln found at the east end of the theatre's stage area (Waterman, Preliminary Report, pl. XVIII, Fig. 2, courtesy of the Kelsey Museum of Archaeology)

Second, the limekilns were mainly found in or around former public monuments (temples, churches, theatres) and peristyle houses. This location corresponds with that of the majority of limekilns found in the urban centres of the Roman East, ${ }^{61}$ and represents those buildings most likely to have been adorned with marble decoration and statuary.

One important matter that remains to be discussed is when these limekilns appeared in the urban context of Sepphoris. This remains an issue because, as mentioned above, excavations and scholarship in general have been little interested in limekilns. The unfortunate result is that the period when these limekilns were constructed and used - two critical aspects for understanding their role within society - often remains obscure at best. In those cases at Sepphoris where a construction date is mentioned, the excavators tend to remain rather vague about it. ${ }^{62}$ While the terminus post quem for all the limekilns at Sepphoris lies in the

61 See above, n. 10.

62 For example, the limekiln found north of the 'Eastern Basilical Building' (Table 10.1:10) is considered to date 'probably after the Byzantine period' (Weiss and Netzer, 'Zippori - 1994-1995': 24). Another example is the two limekilns found on the eastern grounds of the 'Eastern Basilical Building', which are sometimes dated to the Byzantine period (McCollough, 'Monumental 
Byzantine period, there is in two cases some evidence that may provide a more specific construction date. If the chancel screen fragments found in two marble deposits were meant for the nearby limekilns (Table 10.1:11-12), then presumably these limekilns considerably post-date the construction of the nearby fifth century churches. Yet, we should also keep in mind that probably not all limekilns were used at the same time, but that what now is observed represents a long history of reuse of the building material and statuary of ancient Sepphoris. Furthermore, the fact that all limekilns date no earlier than the Byzantine period at least suggests that this was probably the initial period when limekilns were being introduced into Galilee's urban space. This observation is supported by the fourth century account of Epiphanius of Salamis describing the construction of limekilns at Tiberias.

Obviously, this attempt to locate and discuss the limekilns in Galilee remains incomplete. Certain exposed limekilns have probably remained unreported in publication, while many remain invisible to traditional excavations due to their remote, extra-urban location near ancient quarries. ${ }^{63}$ Nonetheless, this discussion shows that, as in other cities of the Roman East, from Late Antiquity onwards limekilns were relatively commonplace within the urban centres of Galilee. Their place within the city limits suggests, furthermore, that the reuse of marble building material and statuary for lime used in building construction played an important role within the society of that time. In the following, I reflect upon the societal motivations behind these changes.

\section{Feeding Marble to the Kilns}

Why did the population begin feeding the sculptural and architectural elements made of marble, which, as elsewhere, once decorated the public monuments and élite mansions in Galilee, to nearby limekilns? The main cause given by scholars for this kind of marble reuse is that it happened for economic reasons. ${ }^{64}$ As mentioned earlier, marble is superior to limestone when it comes to the production of lime. While that is the case, for most of antiquity marble was considered too rare and valuable a commodity to be used for this purpose and was, instead, used primarily for purposes of decoration and lavish display. When, by Late Antiquity, limekilns began to be built within the city limits, scholars reasoned that this was because, by that time, marble was amply available there in the form of architectural decoration and sculpture. Aside from marble's superior quality, reusing this stone from former urban structures nearby also probably saved considerable transportation costs. According to these scholars then, the burning of sculptural and architectural marble in limekilns set up within cities during Late Antiquity

Changes': 273) and at other times attributed to the Early Islamic period (James F. Strange, pers. comm.). For a Byzantine/Early Islamic date, see (Strange et al. 'Zippori - 1991': 30). For some limekilns no construction date is explicitly given. See, for example, Table 10.1:13-14.

63 This last argument was raised by Demierre, 'Les Fours à Chaux en Grèce': 286-7 in the case of Greece.

64 See Peter Stewart, 'The Destruction of Statues in Late Antiquity', in Constructing Identities in Late Antiquity, Richard Miles (ed.) (London: Routledge, 1999): 183-4; Jacobs, 'Production to Destruction?': 291; Greenhalgh, Constantinople to Córdoba: 57; Munro, ‘Sculptural Deposition'. 
was primarily chosen for its productive efficiency: the product was superior and transportation more cost-efficient.

Inherent in this argument about why the late antique population began to reuse urban marble for lime production is that by then this stone came to be valued primarily for its material properties, no matter what the style, representation or context of that marble would have been. Peter Stewart describes the situation of statuary in sixth century Rome thus: 'Divorced from the social and religious circumstances of their creation, the city's statues were at risk: the balance between intrinsic and symbolic value had tipped in favour of the lime-kilns and furnaces. ${ }^{65}$ Ine Jacobs, more recently, has repeated this idea for the eastern empire as a whole: 'The need for raw materials may indeed be the main reason why on the whole we have recovered so little statuary ... of the Late Antique cities of the eastern empire.' ${ }^{66}$

But was 'the need for raw material' really the sole incentive for these people to have stripped the ruins of their marble decoration and to have broken the statuary of the cities into piecemeal fragments ready to be reused as mortar or plaster? Granted, economic incentives would have certainly been in play when deciding on throwing marble into the limekilns. Yet, recent scholarship has highlighted it as the only deciding factor and has, to my opinion, not sufficiently evaluated other possible incentives. The issue with earlier suggestions is that they implicitly assume that throughout the Roman Empire marble's exotic, aesthetic and symbolic qualities had more or less faded by Late Antiquity and, hence, its market value had diminished markedly. This stone-type would otherwise not have been turned into lime, a relatively cheap material that was widely used in building construction.

There is no evidence, however, to indicate that by Late Antiquity the market value of marble would have dropped to such a low that it was more favourable to turn it into lime than to use it as marble. The labour that was put into the quarrying and shaping of the marble into the respective architectural elements, wall veneer and statuary added a considerable value that should not be underestimated. ${ }^{67}$ To this should be added that the admiration for and value of marble would have been higher in regions located further from its source. ${ }^{6}$ A point especially worth considering in the case of Palestine, a region with no marble sources but sufficient local limestone for filling the limekilns. Recent overviews of marble usage in the Roman Empire during Late Antiquity and later sketch a picture of a region in which marble continued to be valued by society for its aesthetic and symbolic qualities. ${ }^{69}$ This

65 Stewart, 'The Destruction of Statues': 183-4.

66 Jacobs, 'Production to Destruction?': 291.

67 For discussion on the demand for and cost of marble, see Ben Russell, The Economics of the Roman Stone Trade (Oxford Studies on the Roman Economy; Oxford: Oxford University Press, 2013): 8-35.

68 Russell, The Economics of the Roman Stone Trade: 14. See Pliny the Elder, Nat., 36.5. Note also how the fifth century Mark the Deacon (Vit. Porph., 84) describes the awe and excitement of Gaza's local population when a cargo of marble intended for the decoration of a church there entered its harbour.

69 Marc Waelkens, 'Marble', in Late Antiquity: A Guide to the Postclassical World, Glen W. Bowersock, Peter R.L. Brown and Oleg Grabar (eds) (Cambridge, MA: Harvard University Press, 
was also shown by the fact that the reuse of marble to decorate public buildings still comprised a substantial industry. ${ }^{70}$ After the marble quarries in the eastern Mediterranean went out of use around the seventh century, the marble reused in new constructions evidently had to come from the former buildings that, at the time, lay in ruins. ${ }^{71}$ Such a reduction in the production of marble would also imply a higher exotic value for this good.

Thus, during Late Antiquity the population still seems to have valued marble as a decorative stone. The columns, statuary, wall veneer and floor slabs made of this material adorning civic spaces were still appreciated, even to such an extent that it was being ripped off on a considerable scale from older structures to be reused in new ones. Questions still remain, however, about why limekilns began to appear in urban areas during Late Antiquity and why these limekilns apparently transformed the highly-appreciated marble into a relatively cheap construction material? What has not been afforded much significance in this regard is the potential symbolic value such limekilns may have had during this period, as well as later on. It is indeed interesting that, where scholars often acknowledge that the use of spolia bore a specific political, religious or cultural message, ${ }^{72}$ such a possibility is disregarded when discussing the purpose of limekilns. While the destructive act of these devices is often cited as a reason why so little marble decoration and statuary from antiquity has been preserved, the reasons for this particular destructive act usually remain undiscussed.

A look at the broader, socio-historical context in which limekilns were first introduced into urban areas, however, provides us with possible indications for their significance. There appear to have been parts of the cities' urban space in which, during Late Antiquity, marble was under substantial threat; that is, when it was used as a decorative stone in pagan monuments and for statuary. During the fourth and

1999): 559-62; Jean-Pierre Sodini, 'Marble and Stoneworking in Byzantium, Seventh-Fifteenth Centuries', in The Economic History of Byzantium, Angeliki E. Laiou (ed.) (DOS 39; Washington: Dumbarton Oaks, 2002): 129-46.

70 For Byzantine sources mentioning the use of marble in the decoration of public buildings, chiefly churches, see Cyril Mango, The Art of the Byzantine Empire, 312-1453: Sources and Documents (Toronto: University of Toronto Press, 1986), s.v. 'marble'.

71 Waelkens, 'Marble': 561-2; Sodini, 'Marble and Stoneworking': 135-45.

72 For example: Beat Brenk, 'Spolia from Constantine to Charlemagne: Aesthetics Versus Ideology', DOP 41 (1987); Helen G. Saradi-Mendelovici, 'Christian Attitudes toward Pagan Monuments in Late Antiquity and Their Legacy in Later Byzantine Centuries', DOP 44 (1990); John Curran, 'Moving Statues in Late Antique Rome: Problems of Perspective', Art History 17 (1994); Helen G. Saradi, 'The Use of Ancient Spolia in Byzantine Monuments: The Archaeological and Literary Evidence', IJCT 3 (1997); The Byzantine City in the Sixth Century: Literary Images and Historical Reality (Athens: Society of Messenian Archaeological Studies, 2006): 366; Sodini, 'Marble and Stoneworking': 145; Robert Coates-Stephens, 'Attitudes to Spolia in Some Late Antique Texts', in Theory and Practice in Late Antique Archaeology, Luke Lavan and William Bowden (eds) (LAA 1; Leiden: Brill, 2003); Jacobs, 'Production to Destruction?'; Troels M. Kristensen, 'The Display of Statues in the Late Antique Cities of the Eastern Mediterranean: Reflections on Memory, Meaning, and Aesthetics', in Debating Urbanism Within and Beyond the Walls A.D. 300-700: Proceedings of a Conference Held at the University of Leicester, 15th November 2008, Denis Sami and Gavin Speed (eds) (Leicester: School of Archaeology and Ancient History, 2010). 
fifth centuries especially, the Christian community launched an offensive against any resilient pagan population and, in their pursuit, physically attacked those physical elements associated with that population, especially statuary and temples. ${ }^{73}$ It should be highlighted, however, that alongside these negative acts of religious violence against the pagan population and culture (so dominant in earlier scholarship), at certain times the Christian community also used more peaceful methods of conversion and held positive attitudes towards the pagan material culture. ${ }^{74}$

What could have been regarded as such a positive response are the numerous Imperial edicts from the mid-fourth to early-fifth century in the Codex Theodosianus that prohibit the removal of statuary or decorative marble from public buildings and spaces. ${ }^{75}$ However, the substantial number of these edicts does suggest that they were issued in response to an act that frequently occurred in the towns and cities of that time. Hence, they should be seen as a testimony that, in reality, the Christian destruction was a severe threat to earlier marble decoration and statuary. Marble was apparently too valuable to the Christian community to be considered appropriate as a decorative stone for buildings and statuary associated with the pagan past.

\section{'All Reduced to Powder': Limekilns and the Destruction of Paganism}

If we take this socio-historical context of a dominant Christian community into account and observe that marble was actually still appreciated in Late Antiquity and later on, it becomes apparent that marble destruction may have been a religiously

73 The scholarly literature on this particular topic is extensive. For some modern discussions, see Cyril Mango, 'Antique Statuary and the Byzantine Beholder', DOP 17 (1963); Liz James, "'Pray Not to Fall into Temptation and Be on Your Guard": Pagan Statues in Christian Constantinople', Gesta 35 (1996); Stewart, 'The Destruction of Statues'; Johannes Hahn, Stephen Emmel and Ulrich Gotter (eds), From Temple to Church: Destruction and Renewal of Local Cultic Topography in Late Antiquity (RGRW 163; Leiden: Brill, 2008); Jacobs, 'Production to Destruction?': 267-8, 282-92. For Palestine in particular, see Yoram Tsafrir 'The Classical Heritage in Late Antique Palestine: The Fate of Freestanding Sculptures', in The Sculptural Environment of the Roman Near East: Reflections on Culture, Ideology, and Power, Yaron Z. Eliav, Elise A. Friedland and Sharon C. Herbert (eds) (ISACR 9; Leuven: Peeters, 2008).

74 For example: Saradi-Mendelovici, 'Christian Attitudes Toward Pagan Monuments'; Michele Salzman, 'Rethinking Pagan-Christian Violence', in Violence in Late Antiquity: Perceptions and Practices, H. A. Drake (ed.) (Aldershot: Ashgate, 2006); Jacobs, 'Production to Destruction?'

75 For example: CTh. 9.17 .2 (in 349); 9.17 .4 (in 356); 15.1 .1 (in 357); 16.10 .8 (in 382); 15.1.25 (in 389); 16.10 .15 (in 399); 15.1 .43 (in 405). For an extensive list, see Waelkens, 'Marble': 562. Later, under Theodoric, an official was appointed specifically to prevent such destruction. Similar orders were made during the Renaissance. In 1534, Pope Paul III issued a directive ordering punishment for plunderers of marble (David A. Levine, 'The Roman Limekilns of the Bamboccianti', The Art Bulletin 70 (1988): 579). See also Cassiodorus' heartfelt plea (Variae 7.13 and 15) in the 530s to preserve Rome's sculptural heritage. A few imperial edicts in the CTh. (16.10.18 [in 399]; 16.10.19.1 (in 407)) actually ordered the destruction of idols. The same happened during the eighth century, when Popes Sisinnius and Gregory II officially sanctioned the use of ancient statuary and ruins to produce lime for the restoration of Rome's city walls (Levine, 'The Roman Limekilns': 579). 
(and politically) meaningful act associated with the destruction of paganism. As will be argued, urban limekilns may have played a vital role in this destructive act.

A substantial amount of archaeological and textual evidence documents how the Christian community during Late Antiquity mutilated pagan statuary, dragged it around in a dismembered state, and then ridiculed it. ${ }^{76}$ As the Syriac bishop Jacob of Sarug describes it in the early sixth century, pagan statues became a pile of fragments 'made to arouse laughter and scorn' ${ }^{77}$ In certain instances, reference is even made to the burning of these statues, as noted for example by Eusebius in the fourth century: 'whatever part of the material [of the statuary] appeared valuable they scraped off and melted in the fire to prove its worth. ${ }^{78}$ To be fair, Eusebius might have meant here statues made out of gold, silver and brass, because of their higher intrinsic value. However, other late antique authors do not make a distinction between precious metals and marble when describing the destruction of statues in late antique towns and cities. ${ }^{79}$ In fact, Jacob of Sarug even explicitly refers to the state of idols and deities as being 'all reduced to powder', an almost direct reference to quicklime. ${ }^{80}$

Important in this regard was the location where the marble was burned. As Peter Stewart notes, 'iconoclasm was not that violence should be done, but that violence should be seen to be done' ${ }^{81}$ It was not so much the erasure of sculptural imagery that was important, but the visibility of this act of erasing. In this respect, the central location of many of the urban limekilns, providing current inhabitants with a visual reference to the destruction of a once dominant culture, appears striking. Thus, the reuse of marble in limekilns located within the cities was not only effective for lime production that could be used within the building industry, but also seems to have stood as a symbol of revenge on paganism. While in earlier times the pagan population had ridiculed the Christian community, now the latter appears to have effectively 'displayed' the end of paganism. The fact that the process of turning marble into quicklime in a limekiln is a slow one that extends over several weeks and is continuous day and night (see above), makes the destruction an obvious and highly visual performance.

Interestingly, it would not have been the last time in history that such a metaphor related to urban limekilns was used. In seventeenth-century Rome, the Dutch painter Pieter van Laer and some of his followers - later to be known as

76 For examples and discussions of these destructive acts, see Greenhalgh, Survival of Roman Antiquities: 203-10; Stewart, 'The Destruction of Statues': 175-80; Saradi, The Byzantine City: 372-4; Tsafrir, 'The Classical Heritage'; Jacobs, 'Production to Destruction?': 282-92; Kristensen, 'The Display of Statues'.

77 Jacob of Sarug, Homily on the Fall of the Idols: 185. See also M. 1'Abbé Martin, 'Discours de Jacques De Saroug sur la Chute des Idoles', ZDMG 29 (1875): 135; Stewart, 'The Destruction of Statues': 179-80.

78 Eusebius, Vit. Const., 3.54. See also Eusebius, Tr. or., 9.6.

79 Jerome, Epist., 107.2; Zacharias Scholasticus, Vit. Sev. (PO 2.1, M.-A. Kugener (ed. and trans.) 1907): 27-35, especially 33.

80 Jacob of Sarug, Homily: 375-80. See also Martin, 'Discours de Jacques De Saroug': 140.

81 Stewart, 'The Destruction of Statues': 167. 


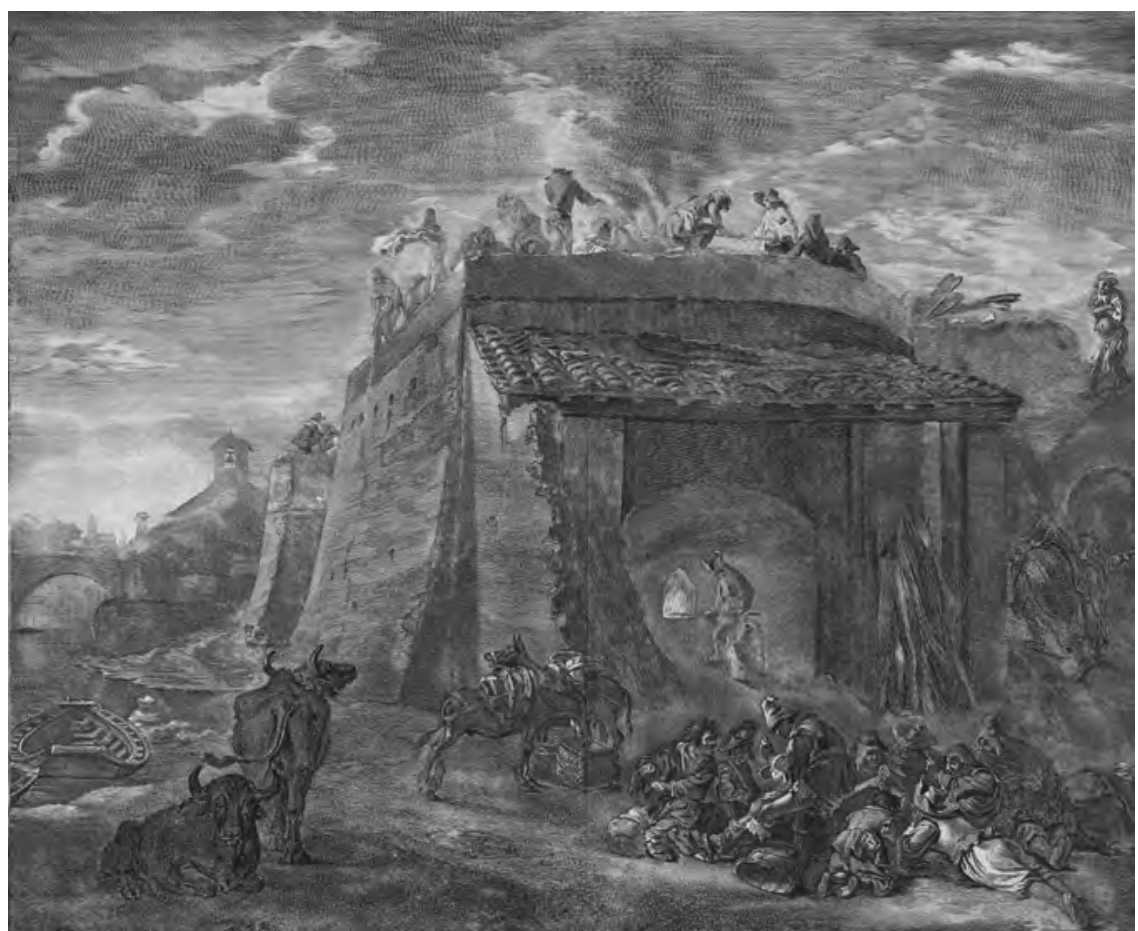

Figure 10.4 Cornelis Visscher, after Pieter van Laer, The Large Limekiln, engraving (RP-P-1904-723; Rijksmuseum, Amsterdam). Van Laer's original painting has been lost; this engraving is probably a mirror-image of it

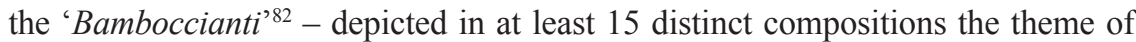
limekilns in Roman settings. ${ }^{83}$ The best-known of these is a painting by Van Laer himself, named The Large Limekiln, which shows an apparently fictional scene of a large limekiln, surrounded by animals, workers and tramps, situated on the banks of the River Tiber (Fig. 10.4). As David Levine has rightly argued, the limekiln's ruinous nature in this painting highlights the critical role of this structure in the eradication of Rome's past. ${ }^{84}$ More importantly, aside from displaying destruction, Levine has argued that Van Laer's limekiln would also have been understood as an allegory for the processes of purification and renewal - 'a metaphor for the regenerative power' of a society ${ }^{85}$ This reminds us to a certain extent of the triumph of

82 The name 'Bamboccianti' derived from il Bamboccio, a nickname given to Van Laer because of his awkward proportions (Levine, 'The Roman Limekilns': 569-70).

83 For a list of these compositions, see Levine, 'The Roman Limekilns': 588-9.

84 Levine, 'The Roman Limekilns': 580.

85 Levine, 'The Roman Limekilns': 580-81. 
the Christian present over the pagan past, as the melting of marble statuary and architectural elements provided a direct economic contribution to contemporaneous society. The limekiln, thus, served as an actor in the societal renewing process.

It has been argued, thus, that the urban limekiln not only provided society with lime, but also provided a deeper meaning embedded in the sociohistorical context of that time. It was a small part of the symbolism surrounding the triumph of Christianity and later Islam over the Classical past. As mentioned, to reduce marble into lime was a process of several weeks' duration. During this process, sculptural marble fragments that were once part of 'animated representations worthy of worship' now, at the hands of Christians and Muslims, became 'lifeless and manmade' ${ }^{86}$ As Michael Greenhalgh has noted, the limekiln highlighted the mortality of both marble and what it represented. ${ }^{87}$ At the same time, however, the substance produced from this marble was of central importance in making the new monuments displaying the triumph of Christianity and, later, Islam.

\section{Conclusions}

This chapter has aimed to reconsider the idea that during the second and third centuries Galilee's built environment was largely vacant of freestanding statues. While most inhabitants of the Roman Empire usually expected to be surrounded by statuary wherever they went within a city, the small amount of preserved remains of especially figurative stone sculpture in Galilee's urban centres has led to the suggestion that Galilee and its population was somehow different. Most of its population, according to some scholars, followed the Biblical and rabbinic prohibition on displaying idolatrous images. Hence, the built environment of its cities was largely devoid of statuary.

With regard to the above argument, however, the evidence of later limekilns in Galilee has usually gone completely unnoticed. Limekilns are nevertheless worthy of consideration, since their presence in urban settings has important repercussions for our understanding of the earlier sculptural and architectural environment there. Indeed, in any discussion on Roman statuary, scholars hasten to add that, from Late Antiquity onwards, unfortunately much of the material that adorned the urban environment - precisely how much remains unknown disappeared into limekilns.

This chapter, therefore, has examined the evidence of limekilns and associated marble deposits in Galilee from Late Antiquity onwards, with a special emphasis on its urban regions. In particular, the extensive excavations at Sepphoris indicate that limekilns were commonplace devices to be found in the urban built environment of Galilee during the Byzantine and Early Islamic periods. Moreover, the evidence of marble statuary fragments near to some limekilns shows that at, a certain time,

86 Kristensen, 'The Display of Statues': 272.

87 Greenhalgh, Constantinople to Córdoba: 57. 
statues would indeed have adorned the built environment of Sepphoris. However, almost all traces of them within the cities have disappeared due to the reuse of these statues for the later construction industry. Indeed, the evidence of limekilns, in urban Galilee especially, suggests that stone statuary was a more common phenomenon than has hitherto been suggested. ${ }^{88}$

What these statues would have represented, who ordered them, and for what reasons remains unknown and requires further study. Nor is it suggested that statuary in Galilee was as common as anywhere else. Obviously, as implied for instance by the considerably larger number of preserved statues in Asia Minor when compared to the Levant, there were regional differences at play with regard to the 'sculptural habit' of a population. ${ }^{89}$ It is, however, suggested that we should nuance our view concerning the practice of setting up statuary in the urban settings of Galilee and show more caution concerning the alleged absence of evidence.

\section{Acknowledgements}

The research for this chapter was supported by the Research Foundation Flanders (FWO) and by the Academy of Finland Centre of Excellence in Changes in Sacred Texts and Traditions. Furthermore, I gratefully wish to thank Professors Byron McCane, James Strange and Zeev Weiss for clarifying matters regarding the limekilns at Sepphoris, as well as Professor Patrick Degryse for discussing Byzantine and Early Islamic glass production in the Levant. I am also thankful to Dr Beth Munro, who kindly provided me with a copy of her forthcoming article on late antique limekilns in the Roman West. Brian Dix, Zeev Weiss, and the Kelsey Museum of Archaeology generously granted me permission to reproduce images. Finally, I wish to thank the editors and the anonymous reviewer for their useful comments and suggestions.

88 A more or less similar explanation has been given for Roman Britain. See Stewart, Statues in Roman Society: 175.

89 On regional differences, see above, n. 14. In light of presumed regional differences, the fact that no statue bases have been found so far in Galilee remains an important aspect to consider, as these were not usually thrown into limekilns. They may, however, have been reused in other ways. 